\title{
Poznámka k recenzní praxi
}

\author{
Milan Blahynka (Horka nad Moravou)
}

Často mě trápí, když čtu recenze, ať už literatury tzv. krásné, at odborné, ba i spisů vědeckých, dost běžný jejich neduh, což vysloveno a zpravidla i svou podstatou je vlastně totéž co ne-duch, absence recenzentova bdělého kritického ducha, a to kupodivu i u recenzentů vzdělaných, kvalifikovaných a ve svém vlastním díle prokázavších rozhled, schopnost hlubinných sond a přesvědčivého podání výsledků svého bádání. Příliš tvrdě a nespravedlivě kritizovaní autoři mívají obvykle za to, že jde o recenzentovu osobní zášt', žárlivost a nepřátelství. Ne že by se vždy mýlili, ale přesvědčil jsem se, že jde mnohdy i o zbytečné, byt pochopitelné nedorozumění; o nedorozumění, které je nežádoucím derivátem čehosi v podstatě chvályhodného a většinou i produktivního, tvưrčího; že nedorozumění vyplývá z toho, co Nezval pojmenoval „zaujetím pro vlastní způsob“. Takové zaujetí přinášívá až překvapivě imponující objevy, má však i svůj rub, to když se střetne se zaujetím pro vlastni zpuisob u díla jiné osobnosti. Když už tu padlo jméno Nezval, připomenu, že spoluobjevitel poetismu nebyl $s$ to dlouho porozumět např́klad Halasovu zaujetí pro jeho způsob poezie a podrobil nespravedlivé kritice už jeho sbírku Kohout plaši $s m r t^{1}$ a až k stáru se Halasova odkazu energicky a odvážně zastal, ${ }^{2}$ aniž rezignoval na svůj vlastní způsob poezie.

$\mathrm{K}$ mé malé poznámce o recenzní praxi mě konečně přiměla recenze objemného, podle mého mínění objevného spisu Identita v litera-

1 NEZVAL, Vítězslav: Kohout plaši smrt. Zvěrokruh 1, listopad 1930, č. 1, s. 45-47. Knižně in: Dílo VN XXIV, Manifesty, eseje a kritické projevy z poetismu. Praha: Československý spisovatel, 1967, s. 324-329.

2 NEZVAL, Vítězslav: Ke Štollovým Třiceti letům a $k$ referátu Jiřiho Taufra. Projev na plenární schůzi spisovatelů 22. 1. 1950 v Obecním domě v Praze. Tento diskusní př́íspěvek mohl vyjít tiskem až in: Dílo VN XXVI, Eseje a projevy po osvobození. Praha: Československý spisovatel, 1976, s. 74-80. tuře Těšinska $a^{3}$, v němž Libor Martinek shrnul, aniž ještě uzavřel, výsledky své mnohaleté literárněhistorické práce. Tu recenzi napsal do akademické České literatury Zdeněk Smolka ${ }^{4}$, který právem požívá (také mé) úcty díky mj. průkazné vědecké obraně identity Petra Bezruče jako autora Slezských pisni $i^{5}$ a jiným studiím.

Jeho recenze už ve druhém odstavci charakterizuje Martinkovu knihu jako „autorskou syntézu nejen proto, že shrnuje poznatky ziskanév prüběhu rady let, ale i proto, že ukazuje dějiny polsky psané literatury sledovaného regionu zhruba od barokni doby až po současnost,“ soudí, že „mezi prednosti práce musime zařadit, že se nevěnuje literárním textům jen jako autonomni oblasti lidské existence, nýbrž že je vřazuje do společenského kontextu [...]. Vzniká tak souhrnný plastický obraz celé problematiky." V posledním odstavci se dostává Martinkově knize nejvyššího ocenění: „Podává jako proni u nás ucelenou informaci o dějinách polské literatury na našem územi, čini tak preciznè, bez závažnějších omyli̊ či nepresností. Nechybi v ní jediný důležitý a podstatný fakt, což je při obsáhlosti tématu obdivuhodné. Libor Martinek odvedl záslužnou práci, která zásadním zprisobem obohacuje poznáni literatury vznikajici na územi našeho dnešniho státu. "V předposledním odstavci je recenze velmi konkrétní, vyzdvihuje se „obdivuhodná schopnost shromáždit utř́dit potřebný materiál, a to včetně méně známých i doposud zcela neznámých pramenů,“ četné monografické podkapitolky „se vyznačuji presností a precizností, většinou i interpretačni zdatnosti,“" Martinek „presně popisuje

3 MARTINEK, Libor: Identita v literatuře Těsinska. Monografie. Kielce-Opava: Ston2 ve spolupráci s Nakladatelstvím Libor Martinek, Literature \& Sciences, 2015. 435 s.

4 SMOLKA, Zdeněk: Historie polské literatury českého Těšinska: Česká literatura 64, 2016, č. 2, s. 288-293.

5 SMOLKA, Zdeněk: Jak jsme se hádali o autorství Slezských pisni: Host 24, 2008, č. 3, s. 38-44. Tam odkazy na autorovy stati Chycený Drozd vaškologický (Česká literatura, 2003), Jak udèlat z básnika zloděje cizích veršu a Záměna žánrů (oboje Tvar, 2004). 
vliv folkloru na autorovu tvorbu,“ „obdobnè je velmi povedený rozbor sbirky [...], a to jak z hlediska popisu jeji poetiky a vyzdviženi použiti těšinského dialektu, tak kviili zhodnoceni jeji reflexe a zdưvodněni jejiho úspěchu."

$\mathrm{V}$ příkrém rozporu s tímto úhrnným kladným hodnocením zabírají největší část recenze (více než tř́i z jejích pěti stran) výhrady a místy příkře vyznívající odsudky Martinkovy metody, skladby knihy a jejich skutečných nebo domnělých nedostatků. Z. Smolka knize vytýká, že „celkově nejde o text specializovaný na problematiku identity, “ že úroveň tří hlavních částí ,je rozkolisaná a jejich obsah ne vždy odpovidá názvu“, že "výcét názori̊ na problematiku identity" působí „jako zjednodu-šené výpisky z četby, aniž by se autor $s$ některým z nich ztotožnil a učinil z nĕj své metodologické východisko,“ „práce pưsobi celkem dojmem metodologického eklekticismu,“" „teoretické reflexe mnohdy nepocházeji z oblasti literárni vědy, a tehdy jsou spiše naivni, bez hlubšiho vhledu do problematiky,“ kapitola o bilingvismu „ničim neprispívá $k$ dalšímu výkladu," druhou část uzavírají „všeobecně známé a zjednodušené, až zbanalizované informace o tom, co je identita [...], tedy to, o čem vlastně mèla pojednávat prvni část, prestože zde by mèlo jít o sumarizaci výsledků části druhé." Jiná část je „souborem dilčich studii, které jsou samy o sobě zajimavé, nevytváreji ušak žádný celek", autor řadu poznatků „nedokázal sloučit do jednotné výkladové linie,“ „z kompozičniho (ale také metodologického) hlediska je tato kniha eintopf."

Domnívám se, že většina těchto námitek plyne z nedorozumění a prrímo protiřečí hodnocení, že kniha podává „souhrnný plastický obraz celé problematiky“. Podává-li kniha opravdu „souhrnný plastický obraz“ jevu, jemuž se věnuje (a v tom s recenzentem plně souhlasím), pak to, pro co má recenze výrazy opovržení („eintopf“, „zbanalizované informace“, „metodologický eklekticismus“) a co je ve skutečnosti promyšlenou metodou mozaiky, vyústilo v úspěšné dílo. Recenzent si stěžuje na Martinkovu metodu, na stránky prý „zcela zbytečné, které spiše ztěžuji a prodlužuji četbu," dokonce tvrdí, že jde o práci „čtenářsky nepřistupnou;“ za to podle něho může „autorova neukázněnost“; jsem rovněž čtenář a stránky domněle zcela zbytečné jsem vítal jako uvádění do atmosféry zkoumaného dění. A nezdá-li se recenzentovi, že teoretické a metodologické pasáže „nalezneme rozesety po řadě jiných mist textu,“ a míní-li, že autor „řadu poznatkư, k nimž se propracoval,“ „nedokázal sloučit do jednotné výkladové linie“ a jinde že „narušuje jednotnou linii výkladu“, je to patrně proto, že si nepoložil otázku, neníli právě nepachtění se za ,jednotnou výkladovou linií" (znamenající téměř vždy riziko zjednodušování) jedním z prostředků autorské strategie. Metoda rozesetí po různých místech není ostatně cizí ani recenzentovi, který své namítání proti domnělému nesouladu názvu částí a podčástí s jejich obsahem pranýřuje ve 3., 4., 6., 10., 11. odstavci a nepřímo i v jiných, kam je z hlediska, které sleduje, správně rozesel. Totéž platí i o jeho nechuti ke zdánlivě zbytnému opakování. Sečteno a podtrženo: výhrady a ostré kritické výtky vyplývají ze Smolkova zaujetí pro jeho způsob, který spočívá v úsilí o „souvislý literárněhistorický výklad“, jaký Martinkovy kapitoly a kapitolky prý „v konečném výsledku“ pouze „supluji“; o recenzentově poctivosti svědčí, že napsal „zdárně supluji“. Recenze je vlastně konfesí, jak by recenzent psal knihu o identitě polské literatury na Těšínsku, kdyby ji sám psal. Přesvědčivosti recenze, vynášející verdikt „nezvládnutá kompozice“, samozřejmě nedodají smělá tvrzení o tom, že zařazením jinam by některé pasáže „puisobily daleko přirozeněji.“ Tu by se recenzent dobral uvěřitelnějšího zjištění, kdyby se - na základě svého respektu $\mathrm{k}$ autorovu umění vyhledávat a podávat „podstatné informa$c e^{\text {“ }}$ - radši zamyslel nad tím, zda přece jen nemá zdánlivě neústrojné jejich místo $\mathrm{v}$ textu logiku a plné oprávnění.

Jak nebezpečné je dávat přednost námitkám před úsilím o pochopení, to ukazuje onen odstavec recenze, kde Zdeněk Smolka demonstruje Martinkovo údajné „nepatrǐčné používáni některých pojmü“. Za př́klad považuje Martinkův výrok: „doširoka otevřený prostor básně obsahujici celý svět se ve finále zužuje na jedinou zemi - Polsko. (Prostor básně procházi fenomenologickou redukci.).“" Tomu se recenzent vysmívá: „Zúženi geografického prostoru nemá samozřejmě s fenomenologickou 
redukci - která je metodou filozofického zkoumáni, již zavedl Edmund Husserl - nic společného. Fakt je, že je něco redukováno, ještě neznamená, že jde o fenomenologii. Martinek se zde nechal svést kolokabilitou slova redukce, aniž by spojeni fenomenologická redukce rozuměl či alespoñ tušil, co znamená."

Tady si nelze nevybavit latinské úsloví sus $M i$ nervam docet. Martinek se právem ohradil a poukázal na svou znalost polské vědy, zejména Romana Ingardena, takže víc než tušil, co znamená fenomenologie pro výklad literárního díla. ${ }^{6}$ Recenzentova domněnka, že zúžení geografického prostoru v básni „nemá samozřjejmě nic společného s fenomenologickou redukci“, je tvrzení tím trap-

6 MARTINEK, Libor: Polemika $k$ recenzi Zdeňka Smolky Historie polské literatury čského Těšinska: http:// www.ucl.cas.cz/cs/casopis-ceska-literatura/ceska-teratura-v-siti/2212-ad-zdenka-smolka-historie-polske-literatury-ceskeho-tesinska-polemika; navštíveno 26. 12. 2017. Martinkova zevrubná polemika systematicky vyvrací recenzentovy námitky proti metodě, ukazuje napr., že zmínka, podle níž „téměr tř́stránková pasáž o bilingvismu“, shrnující dosavadní názory „na tento jev“, podle recenzentova mínění „ničím nepřispívá $k$ dalšimu výkladu,“ je přinejmenším kruté přehlédnutí, nebot je to nutný úvod do analýzy řady sbírek a zjištění v řadě kapitol. Podobně recenzentova nespokojenost se zdánlivou diskrepancí mezi názvy (celé knihy i některých jejich částí) a textem, který následuje, namítání, že „rada kapitol má nevhodný titulek, obsahuji něco jiného, než co označuje název, " vyplývá z velmi zúžené představy o názvech; Smolkovu výhradu k názvu kapitolky Symbolika mostu v těšinské poezii (že mostu se týkají pouhé dva odstavce) Martinek usvědčuje z neporozumění metaforickému významu slova most. nějšsí, že hned v roce 1947 publikoval J. B. Čapek studii Redukce v myšleni a v umělecké tvorbĕ, upozorňující už v prvním odstavci, že „problém redukce,“ který „v moderni filozofii a metodologii stoji v popředi zájmu, “ nebyl „v teorii uměni dosud náležitě doceněn, ač v umèni samém nalézáme radu přikladů redukce dokonané a dokonalé. " $\mathrm{J}$. B. Čapek pak zavádí přímo termín „básnická redukce“ a připomíná: „Moderní poezie evropská po překonáni zálib rétorických a slovně maliřských počala také směrovat $k$ redukci jako prostředku oproštujicímu a výběrnému, který se bliži vlastni podstatě básnictví." Nevím, zda Martinek už znal českou studii o básnické redukci ve Slovesné vědě 1947, když napsal, že prostor Jasiczkovy básně „procházi fenomenologickou redukcí, anebo $\mathrm{k}$ tomu závěru dospěl samostatně; na tom koneckonců nezáleží. Rozhodující je, že nejde o „nepatřičné používání některých pojmů.“

Recenzentská práce je snad ještě rizikovější než předpovídání počasí a vůbec budoucnosti. A nejméně jí sluší bohorovná suverénnost a sarkasmus, který občas ukáže, kdo vlastně ani netuší.

7 C̆APEK, J. B.: Redukce $v$ myšleni a v umèlecké tvorbě. Slovesná věda 1,1947 , č. 1, 16. 10., s. 23-31. Termín básnická redukce, který razil J. B. Čapek, nevešel do jazyka literární historie a kritiky, jak jeho dokládá absence v rejstřících většiny příruček poetiky a literární teorie a slovníků.

\section{PhDr. Milan Blahynka, CSc.}

emeritní vědecký pracovník Ústavu pro českou a světovou literaturu ČSAV

Horka nad Moravou, Česká republika

milanblahynka@seznam.cz 